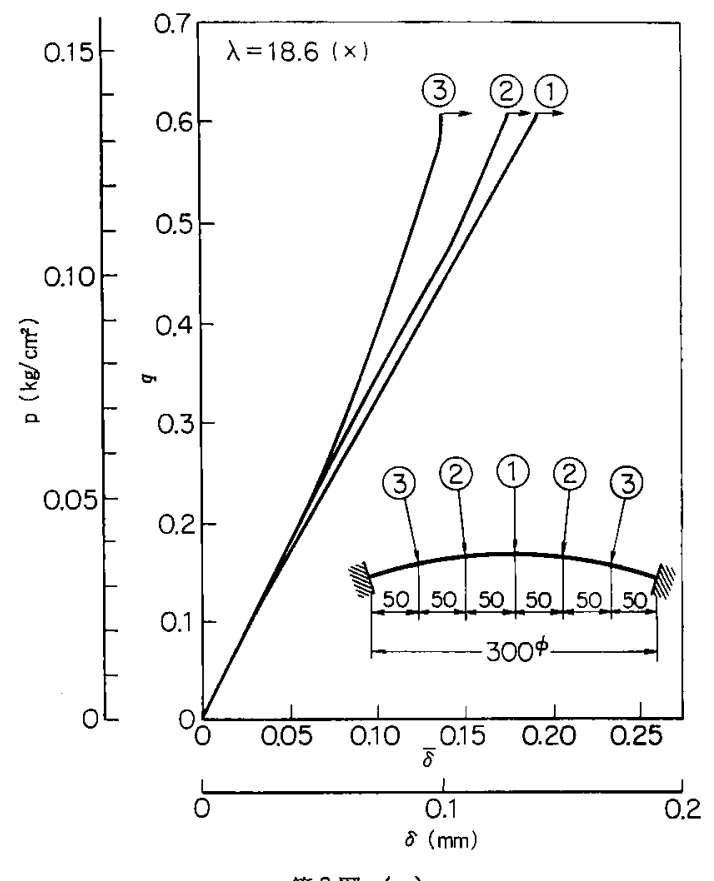

第 8 园（e）

く僅かに違う球形亮の状態に移ると考えれば，上述の 点は理解できるのではなからうか.

筆者等が大きな興味を持っている3 挫屈発生時の波 形は高速度撮影により既に数多く捕捉しており，光弾 性模型による観察之共に続報に於て報告する予定であ る.
文献

1) 杪川 惠, 市田和夫：球形亮の外压による挫届に関す る研究(第 1 報), 日本航空宇宙学会誌, 21 (昭48), 263.

2) 悠井 規, 砂川 㭧: 浅い粘弾性球形款の動的挙動, 同上, 19 (昭 46), 452.

3）砂川 惠: 球形殻の挫屁に関する最近の研究動向, 同 上, 16 (昭 43 ), 236 .

\title{
電子衝撃型イオン・エンジンの研究 (2)
}

電力消費の最適制御法について*

\section{Development of Electron Bombardment Ion Engine (2)}

Optimum Method of Electric Power Consumption

$$
\text { 工藤勲** ·村上寛**.中山勝 矢** }
$$

Isao Kudo, Hiroshi Murakami and Katsuya NaKayama

\section{Abstract}

Three dimensional analysis is made with respect to electric power consumption of the electron bombardment ion engine at an orbital transfer or a station keeping of an artificial satellite.

The optimum position for the ion engine operation is determined, and three types of control are possible to compensate for a change of thrust level. Variations of power are calculated, and the most advantageous control method is obtained.

\footnotetext{
* 昭和 47 年 12 月 7 日原稿受理

** 工業技術院電子技術総合研究所
}

It is clarified that propellant fllow control, which is usually adopted, does not necessarily give optimum one. The change of accelerating voltage does not need more propellant, but may go unsteble owing to changes in position of plasma boundary. When the ion production cost is changed, the shift to the optimum point is required to operate at minimum power consumption.

\section{1. 緒 論}

日本においても，近い将来，通信衛星や放送衛星等 の大容量で，しかも，5年ないし 10:年の長い間作動 
する商業衛星が実用化されるむのと思われる。一つに は，乙のような衛星を，月や太陽の引力，地球の重力 場の业み，太陽風等の外乱住対して，精度良く位置を 保持するとと，また，一つには，大容量の衛星を大型 のロケットを開発することなく，経済的に静止軌道に 打ち上げる方法が，電気口ケットを採用するととによ り可能で，とれらについてのミッション解析が各国で 真剣にとりくまれている12-14).

イオン・エンジンを，単に深宇宙探査用に使用する だけでなく，地球に近い軌道での制御用として用いる ことも極めて與味樑いものである。

第 1 報において，アルゴンを燃料とした電子衝揧 型イオン・エンジンの基本的な特性について報告し た ${ }^{15)}$ ，電気口ケットは，その性格上，然料の消費は， 従来の化学ロケットに比して十分に小さいが，その名 の示すとおり，電力を心要とする，電力源には，太陽 電池加適当と考えられるが，その効率加ら考えて，使 用電力をいか心小さくするかというととが，電気口ケ ットの生命線となろう.

従来のロケットの制御法では，然料消費を最小にす るととが主題であったが，電気ロケットでは，比推力 が析違いに大きく，それよりはむしろ，使用電力量 を最小にする制御法がより重要之思われる ${ }^{16)}$. 今回 は，きびしい電力制限下に怙いて，いかにしてイオ ン・エンジンを最適に運転するかという問題を，三次 元モデルを中心に述べる17》.

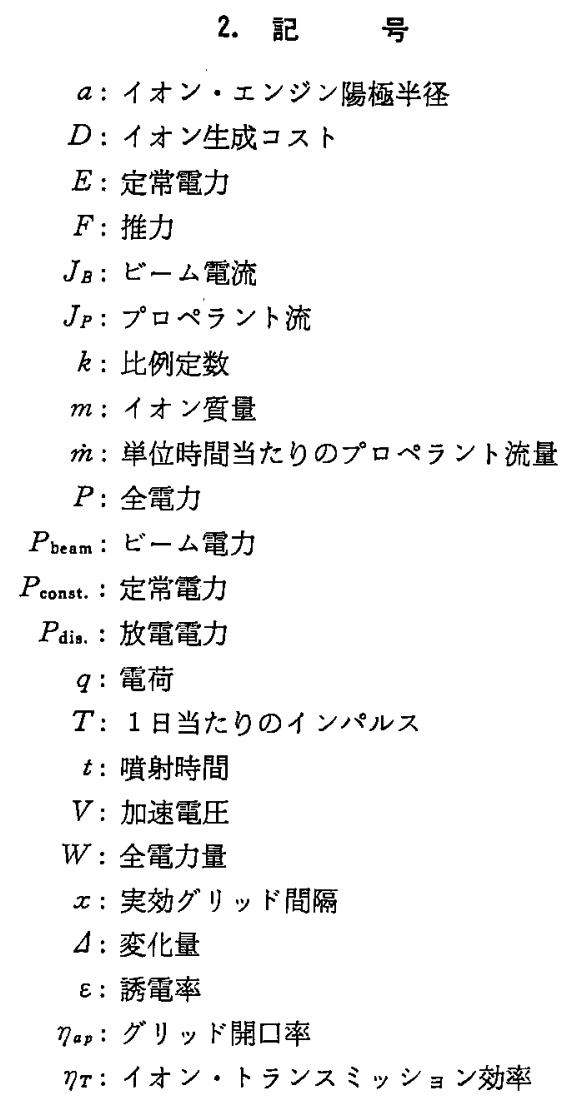

3. 最適運転位置

電子衛撃型イオン・エンジンを運転するとき，以下

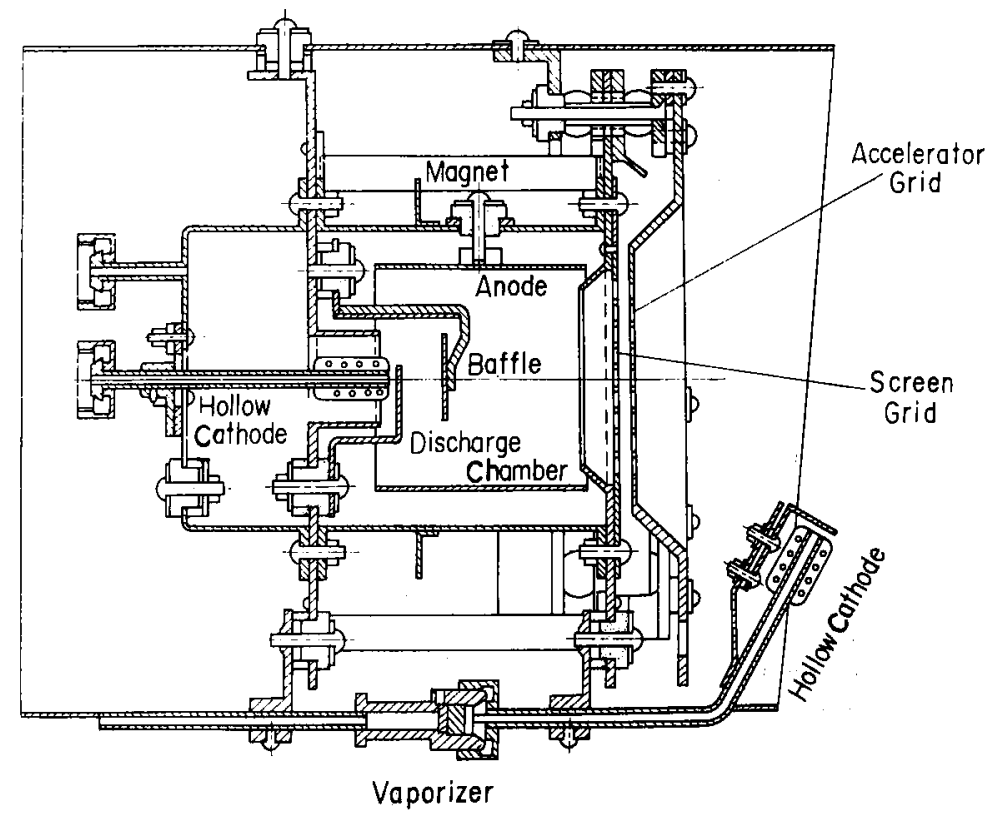

第 1 図 電子衝慗型イオン・エンジン断面図 
に示す制限を満足する心要がある.

1) 空間電荷制限 イオン・エンジンの設計図を第 1 図に示す.この図で，二枚のグリッド間に電圧を印 加して, 引き出し得るイオン電流は，ちょうど, 二極 真空管の電子電流にあてはまる CHILD-LANGMUIR の 法則飞従う。

$$
J_{B}=\frac{4 \pi}{9} \cdot \sqrt{\frac{2 e}{m}} \cdot \frac{V^{3 / 2}}{x^{2}} \eta_{a p} \cdot \pi a^{2}
$$

2）絶緑破壊制限 第 1 図化おいて，スクリーン。 グリッドには，ほぼ正味の加速電圧がかが，アクセ ラレーター・グリッドには，中和器からの電子の逆流 を防ぐために負の電圧汃印加される，乙のように，2 枚のグリッド間には高電界が存在する。グリッド間 はルビー・ボールで絶縁されてはいるが，プラズマ が存在するととから，絶縁破壊が起とりやすい，2,000 $\mathrm{V} / \mathrm{mm}$ 以上の高電界は，現実的に眀加することがで きず，これが電圧の制限となる。

$$
V_{\max }=2,000 \times x
$$

3）燃料制限 エンジンに供給するプロペラント

$$
J_{p}=\frac{\dot{m}}{m} q
$$

以上のビーム電流をエンジンはとるととができない，

4）電力量制限 イオン・エンジンが使いうる最大 の電力量は, 衛星のもつ太陽電池の出力化依存する.

一日当たり心要とする推力量を $T(=F \cdot t)$ とすると， それ比要する電力量は,

$$
\begin{aligned}
W & =P \cdot t \\
& =\left(P_{\text {beam }}+P_{\text {dis }}+P_{\text {const }}\right) \cdot t \\
& =\frac{T\left\{V \cdot J_{B}+D \cdot J_{B} / \eta_{\mathrm{T}}+E\right\}}{V \overline{2 m / e} \cdot V \bar{V} \cdot J_{B}}
\end{aligned}
$$

で与えられ，ての量は，決められた電力量以下でなり ればならない。

第 $(4)$ 式で，電力量 $W$ は，ビーム電流 $J_{B}$ に対し ては，単調減少，加速電圧 $V$ 亿対しては，最小値を 持ち，特に第 2 図，第 3 図，第 4 図住，電力量之加速 電压の関係を示したもので, 加速電圧の高い場合, グ リッド間距離 $x$, 定常電力 $E$ を変化してす， あまり 電力量に影響を及はささない，てれら四種の制限下での 運転領域を三次元モデルで，第 5 図に示す．乙の図 で, $A^{\prime} B^{\prime} E^{\prime} O^{\prime}$ は電力量制限をあらわし，エンジン は，との平面以下で運転しなくてはならない，すなわ ち，曲線 $D^{\prime} H^{\prime} G^{\prime} B^{\prime}$ を縁とする下に凸の曲面上が運 転許容領域となる. 直線 $A B$ は, $V=V_{\max }$ を示し, 曲線 $O^{\prime} H^{\prime} F^{\prime} C^{\prime}$ は空間電荷制限で, また, 直線 $E B$ は， $J_{B}=J_{P}$ の然料制限を表わす. プラズマ境界面が 固定していれば， $H^{\prime} F^{\prime} C^{\prime}$ が，運転可能な曲線となる この曲線上において，電力量の最小点が存在する. （4)式に（1)式を代入して
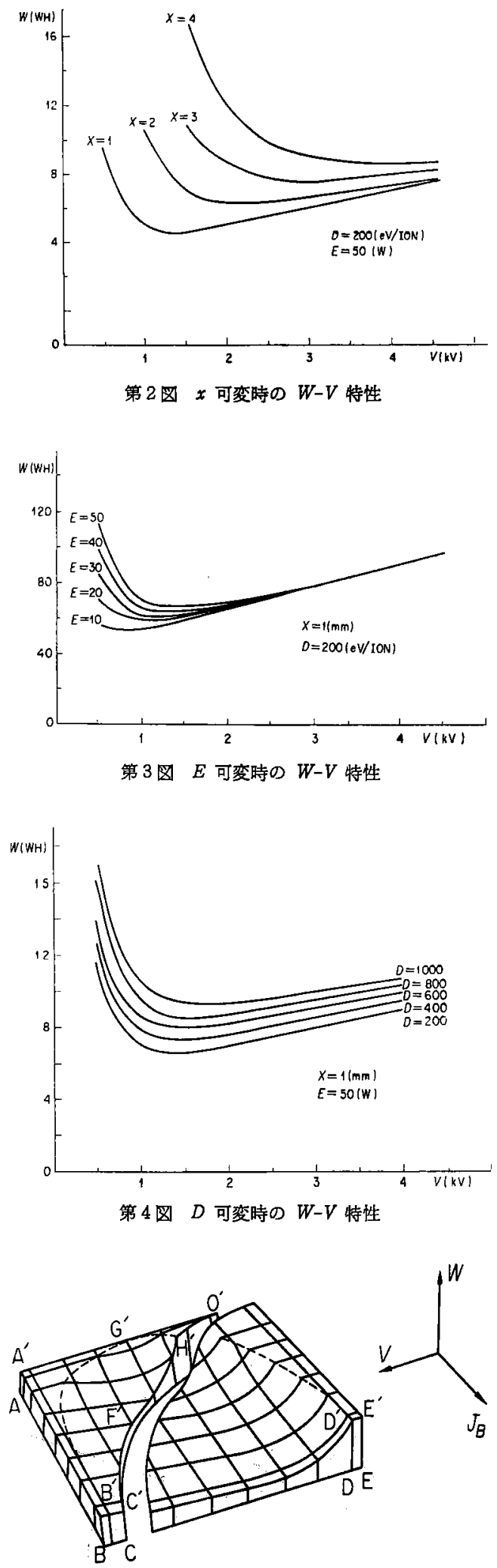

第 5 図 三次元モデル 


$$
W=\frac{T x^{2}}{V \overline{2 m / e} k}\left\{k \frac{V^{5 / 2}}{x^{2}}+k \frac{D V^{3 / 2}}{\eta_{T} x^{2}}+E\right\} / V^{2}
$$

とこで

$$
\begin{aligned}
& k=\frac{4 \varepsilon \eta_{a p} \pi a^{2}}{9 \sqrt{m / 2 e}} \\
& \begin{aligned}
\frac{d W}{d V}= & \frac{T x^{2}}{k \sqrt{2 m / e}}\left\{k \frac{V^{3}}{2 x^{2}}-k \frac{D V^{2}}{2 \eta_{T} x^{2}}\right. \\
& -2 E V V\} / V \overline{V^{7}}
\end{aligned}
\end{aligned}
$$

$d W / d V=0$ で，W は，極值を持つ. ゆえに

$$
k \frac{V^{3}}{2 x^{2}}-k \frac{D V^{2}}{2 \eta_{T} x^{2}}-2 E V \bar{V}=0
$$

これを整理して

$$
V^{2}\left(V-\frac{D}{\eta_{T}}\right)=\frac{9 \sqrt{m / 2 e} E x^{2} V \bar{V}}{\varepsilon \eta_{a_{F}} \pi a^{2}}
$$

最適運転電圧は，（9)式の根として求まる．第(9) 式は，V関する5次方程式であるが，第 6 図保見る ように意味のある根は，一根のみである. イオン生成 コスト $D$ ，実効グリッド間距離 $x$ を，それぞれ変化

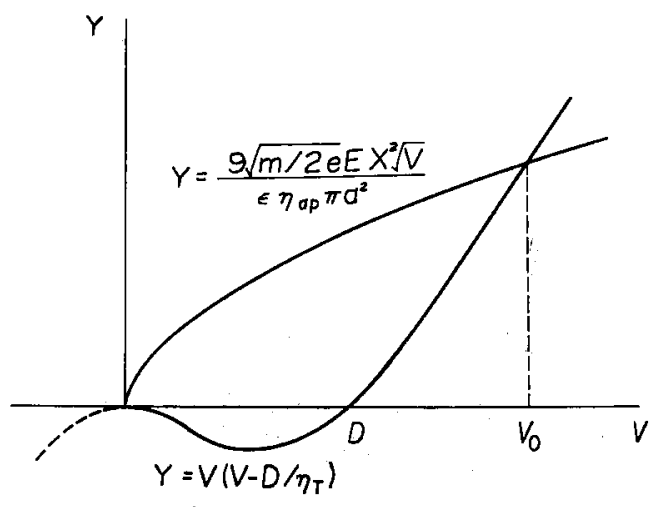

第 6 図 5 次方程式の解

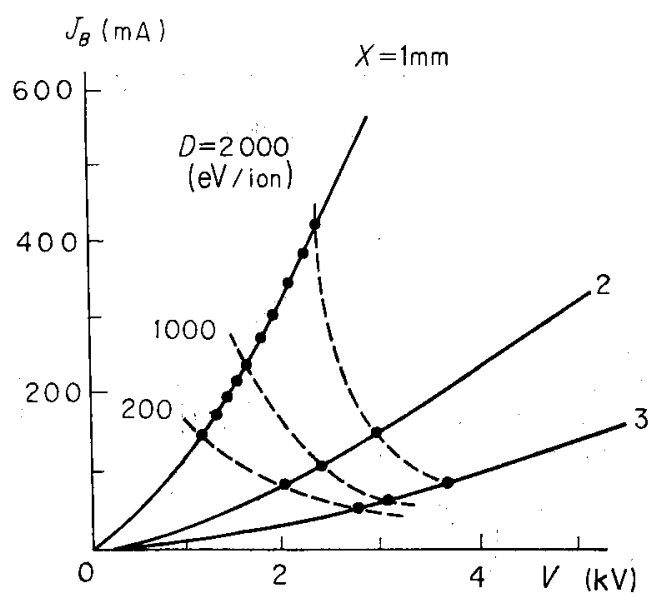

第 7 図 最適運転地図

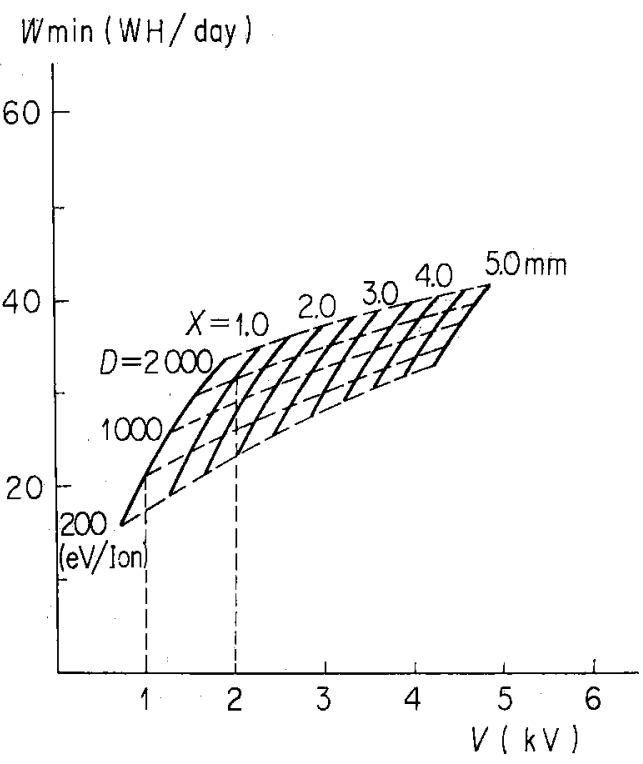

第 8 図 最小電力量

したときの電力量最小の位置を示したグラフを，第 7 図に示す.たとえば， $x=1 \mathrm{~mm}$ で， $D=1,000 \mathrm{eV} /$ ion $E=50 \mathrm{~W}$ が与えられているとき，最適運転位置は， $V=1,640 V, J_{B}=235 m A$, となる：むちろん，上述 の 2)，3，4) の制限が満たされているかきり，CHILD の式で, $x=1 \mathrm{~mm}$ の曲線上の点はすべて運軽可能で あるが，上の例は，その最適運転点をあらわす．第 (4)式が示すように，モデルの形は，Tに独立であ る. 第 8 図は， $E=50 \mathrm{~W}$ において，それぞれの $V$, $x, D$ 儿対する最小電力量值を図示したものである。

\section{4. 制御 法}

3で述べた最小電力量に関するモデルを，イオン・ エンジンの制御に応用する.

$$
T=\sqrt{\frac{2 m}{e}} \sqrt{V} J_{B} t
$$

(10)式は，制御変数として，加速電生，ビーム電 流，喏射時間の三種類が考えられることを示してい る.これからめ後は，エンジンに何らかの変化が起と って, 推力レべルが変わった際の三種の制御法につい て述べる、エンジンは，最初， $V_{0} Ｊ_{B 0}, \mathrm{D}_{0}, x_{0}$ で 与えられる最適運軽位置にあるすのとする.

1），加速電任の変化による制御 第 9 図(a)に示す ように，ビーム電流が $J_{B 0}$ から，J $J_{B 1}$ に変化して推力 レベルが落ちた場合，これは，第(1)式におけるxの 変化：すなわち，イオン化室下流のプラズマ境界面が 後退したと見ることができる。新しいプラズマ境界面 で, 所要のインパルスを得るために，加速電压のみを 変化させた場合, 
電子衝撃型イオン・エンジンの研究 ( 2 )（工藤勲，村上寛，中山勝矢）

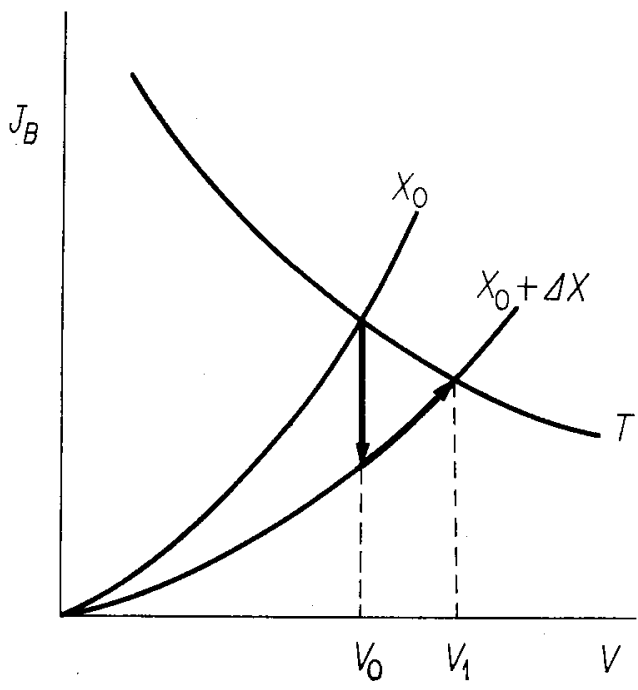

第 9 図(a) 加速電圧の変化による補償 $J_{B}-V$ 面
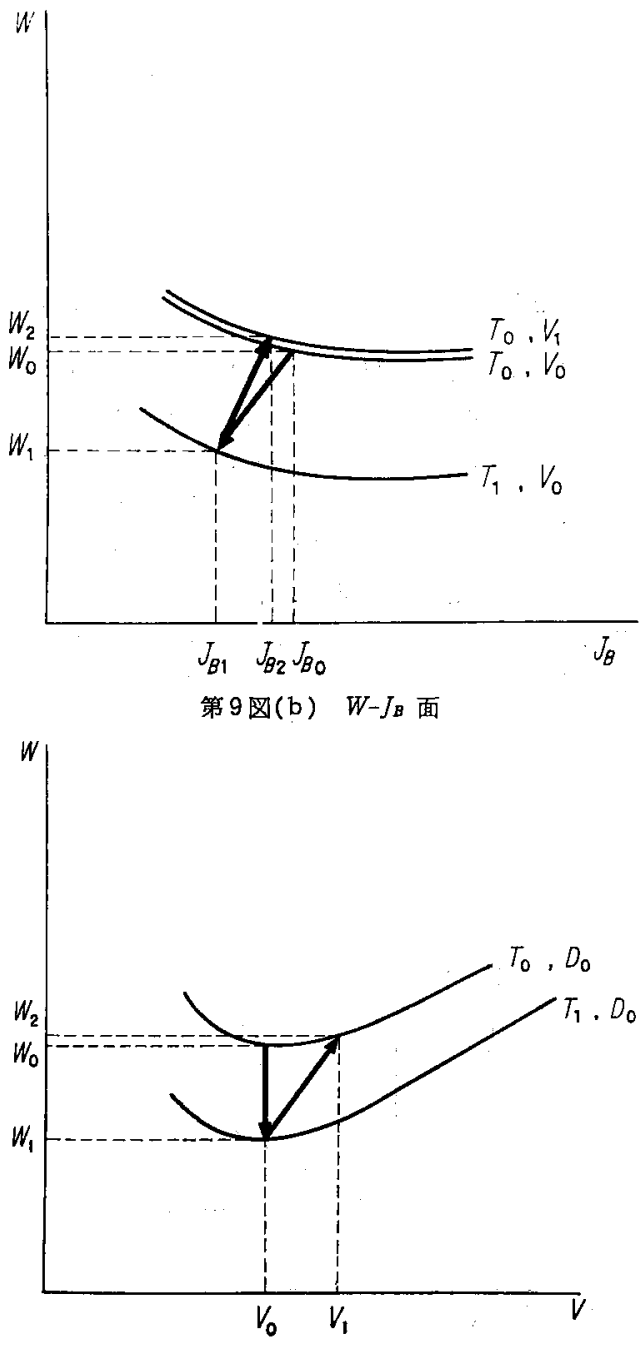

第 9 园(c) $W-V$ 面

$$
T=\sqrt{\frac{2 m}{e}} V \overline{V_{0}} J_{B 0} t_{0}=\sqrt{\frac{2 m}{e}} V \overline{V_{1}} J_{B 1} t_{0}
$$

ここで $V_{1}=V_{0}+\Delta V, x_{1}=x_{0}+\Delta x$ とすると， CHILD の式で

$$
\frac{V_{0}}{x_{0}}=\frac{V_{1}}{X_{1}}=\frac{V_{0}+\Delta V}{x_{0}+\Delta x}
$$

なる関係があることに注意して，制御の前後の電力量 の変化を求めると

$$
\begin{aligned}
\Delta W_{V}= & W_{1}-W_{0} \\
= & {\left[k\left(\frac{V_{1}^{5 / 2}}{x_{1}{ }^{2}}-\frac{V_{0}^{5 / 2}}{x_{0}{ }^{2}}\right)+k \frac{D_{0}}{\eta_{T}}\left(\frac{V_{1}^{3 / 2}}{x_{1}{ }^{2}}\right.\right.} \\
& \left.\left.-\frac{V_{0}^{3 / 2}}{x_{0}{ }^{2}}\right)\right] t_{0}
\end{aligned}
$$

整理して

$$
\begin{aligned}
\Delta W_{V}= & \frac{T\left(\sqrt{V_{0}+\Delta V^{*}}\right.}{\sqrt{2 m / e}} \\
& \frac{\left.*-V \overline{V_{0}}\right)\left(\sqrt{\left(V_{0}+\Delta V\right) V_{0}}-D_{0} / \eta_{T}\right)}{\sqrt{\left(V_{0}+\Delta V\right) V_{0}}}
\end{aligned}
$$

$W-J_{B}$ 面， $W-V$ 面化おける変化を第 9 図(b), (c)化示す.

2）イオン化室のプラズマ密度を変化させる制御 プラズマ境界面の変化は，プラズマ境界面に入射して くるイオン密度の增減之考えるととができ，第 10 図 の場合は，イオン化室での電離効率をあげるか，ある いは，エンジンへの然料供給量を增加することにより 補償が可能である：この際の变化は，イオン生成コス ト D の変化として报われる. 電力量の変化は

$$
\Delta W_{\mathrm{dis}}=k \frac{D_{1} V_{0}^{3 / 2}}{x_{0}{ }^{2}} t_{0}-k \frac{D_{0} V_{0}^{3 / 2}}{x_{0}{ }^{2}} t_{0}
$$

整理して

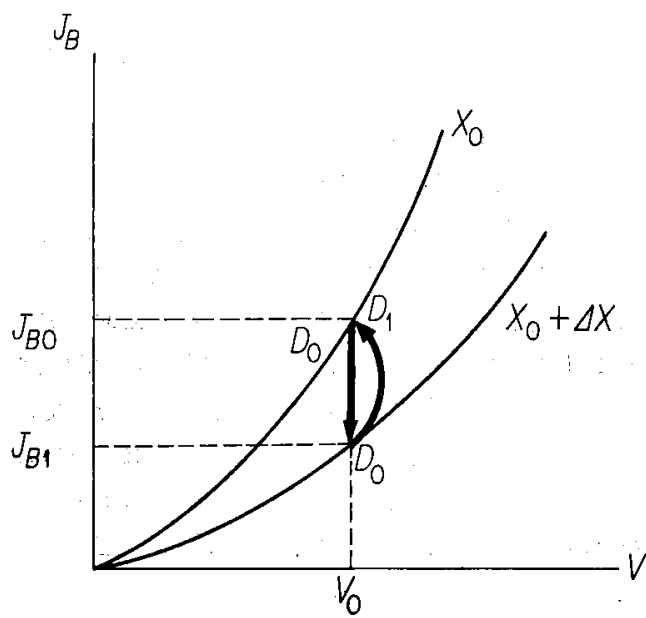

第 10 図 イオン化室のプラズマ密度を变化させる ことによる補償 


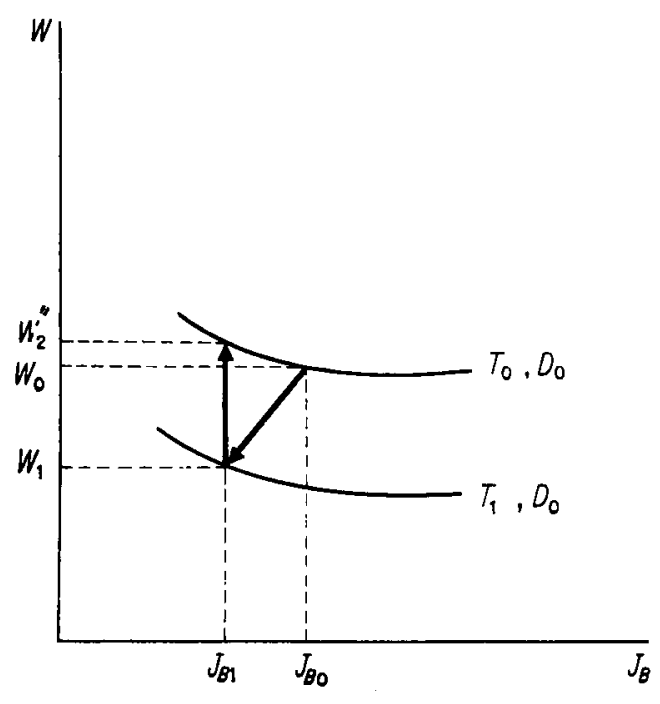

第11因 噴射時間の変化による補供

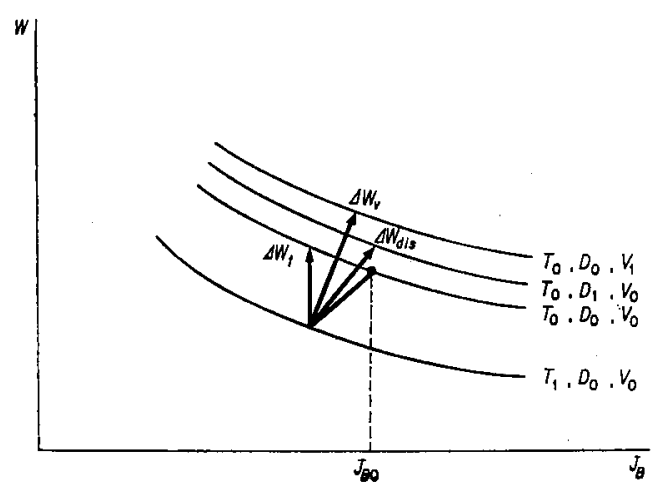

第 12 図 制御法比较

$$
\Delta W_{\mathrm{dia}}=\frac{T\left(D_{1}-D_{0}\right)}{\sqrt{2 m / e} \sqrt{V_{0}}}
$$

3）噴射時間の制御 推力レベルが落ちた場合，そ れをとのままにして，噴射時間を延長する補償法であ る. この際の電力量変化は

$$
\Delta W t=E\left(t_{1}-t_{0}\right)
$$

第 11 因は，W-J $W$ 面での変化の模様を示す.

第 12 図は，W-J 面における電力量の比較であ るが，との図にみる順序がいつあ成立するのではなく 種々の状況下で変化する. 今 2) の制御法代いて, イオン生成コストの変化は, 電離効率と密接な関係を 持ち，正確に定量化することがむ゙ずかしい，そこで， 1)，3）の電力量変化 $\Delta W_{V}, \Delta W$ ，がともに， $\Delta W_{\text {di }}$ に等しい之置いたときのイオン生成コストの変化 $\Delta D=D_{1}-D_{2}$ を求め，それを指標にして，三種の制 御法を比較するととにする.

$$
\Delta D_{1}=\frac{\Delta W_{V} \sqrt{2 m / e} V \bar{V}}{T}
$$

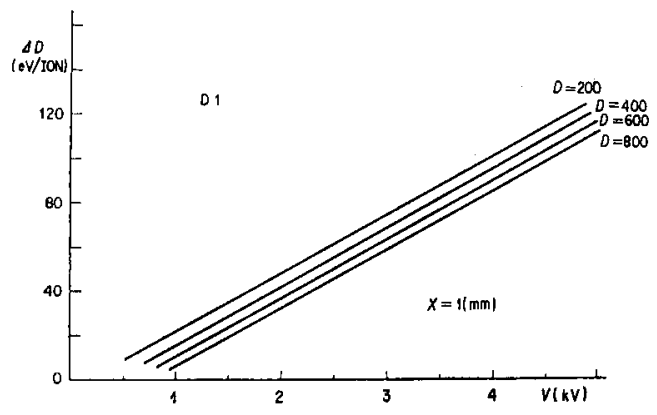

第13図 $\Delta W_{V}, \Delta W_{\mathrm{d} \mid \mathrm{a}}$ の比較

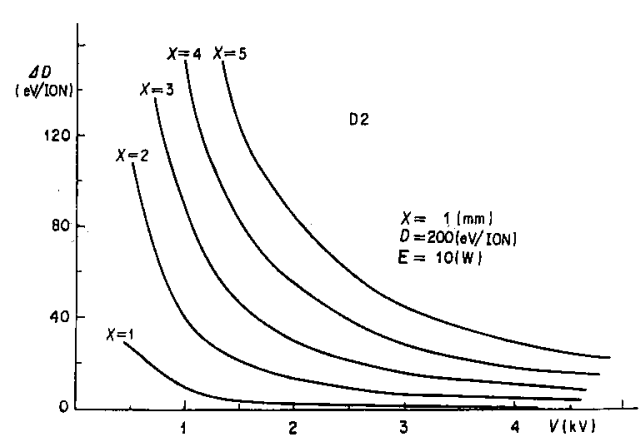

第 14 図 $\Delta W_{t}, \Delta W_{\mathrm{d} 1 \mathrm{~g}}$ の比較

$$
\Delta D_{2}=\frac{\Delta W_{1} V \sqrt{2 m / e} \sqrt{V}}{T}
$$

第 13 図は，緥軸 $\Delta D_{1}$, 横軸 $V$ として, $D$ を変 化したときの曲線群で，この曲線より上の領域に，2) の制御でのイオン生成コスト $D$ の変化量 $\Delta D$ があ ると， $\Delta W_{\mathrm{dis}}>\Delta W_{V}$ で， 1) の加速電圧の変化による 制御が，2）のイオン化室のプラズマ密度を変化させ る制御より有利となる，曲線の下では，この関係が逆 転する．また，第 14 図は， $\Delta D_{2}-V$ の関係を示し たもので， $x$ を変化したときの曲線群である．この図

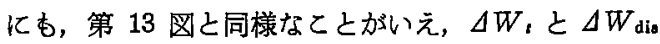
の比較をすることができる，第 15 図は，との2枚の グラフから合成したもので，領域は六通りに分りられ る. 各領域において一番電力量変化が小さいものが最

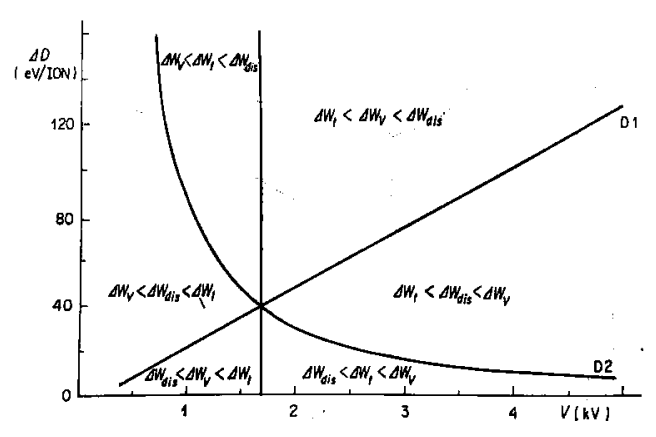
第 15 図制御地図 


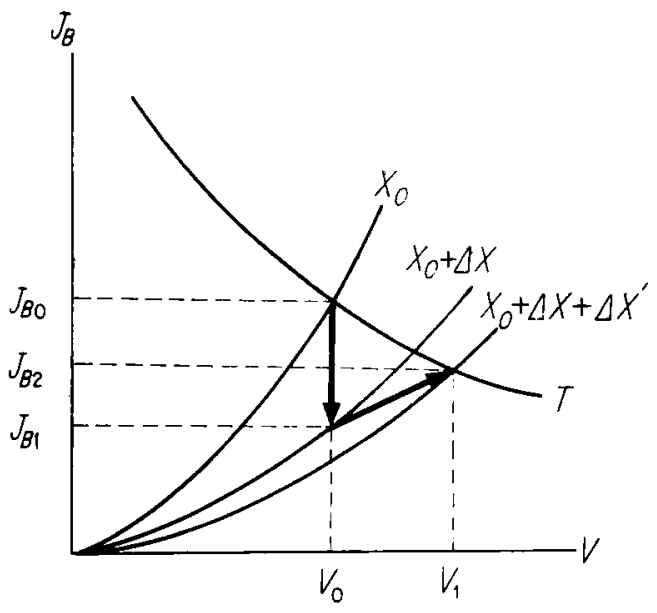

第 16 図 加速笪王变化によるプラズマ境界位置の 変化を考虑した場合

適な制御法といえる，この図にみる如く，制御法の優 劣は固定したものではなく，状態適応した制御をす る必要がある.

以上の解析においては，推カレベルの変動を補償す るための加速電圧の変化にともなうプラズマ境界面の 挙動や，イオン生成コストの変化により，すはや，エ ンジンが最適運転位置に扔いて運転していないてと等 を無視してきた。これからは，これらを考慮に入れた より詳細な解析を試みる。

第 16 図は，制御のために加速電圧を上昇したとと により，プラズマ境界面が，さらに， $\Delta x^{\prime}$ 変化し，実 効的なグリッド間距離は， $x_{0}+\Delta x+\Delta x^{\prime}$ となり，プ ラズマ境界面が後退したてとを意味する．乙の変化の ために，また推力レベルが維持されず，乙の変化分を 補償するために，加速電圧を変化させる心要がでてく る. との繰り返しを続けて，境界面の変動をある許容 レベル内に入るまで制御するあのとすると， $n$ 回後の $x$ の徵小変化分は,

$$
\begin{aligned}
\Delta x_{n} & =S\left(V_{n}-V_{n-1}\right) \\
& =\left(S \frac{V_{0}}{x_{0}}\right)^{n}\left(x_{1}-x_{0}\right)
\end{aligned}
$$

となる. こてで， $S$ は比例定数

今, $\left(S V_{0} / x_{0}\right)<1$ であれば(20)式の右辺は収束する が，たとえば， $V_{0}=2,000 V, x_{0}=2 \mathrm{~mm}$ であるとき， $S>10^{-6} \mathrm{~mm} / V$ の場合は，発散して制御不能となる.

さきの 2) の制御法において，イオン生成コストD の変化は，第 7 図にみるように，最適運転位置が変わ り，乙の状況下では，上り消費電力量が小さい運転位 置が存在し, 第 17 図は, 乙の変化の過程を $J_{B}-V$ 面で示したあのである．特第 18 図は，W- $V$ 面で の表示で，より $W$ が小さい点への変化がはっきり上 わかる，この最適運転位置への移行は，電压の変化に

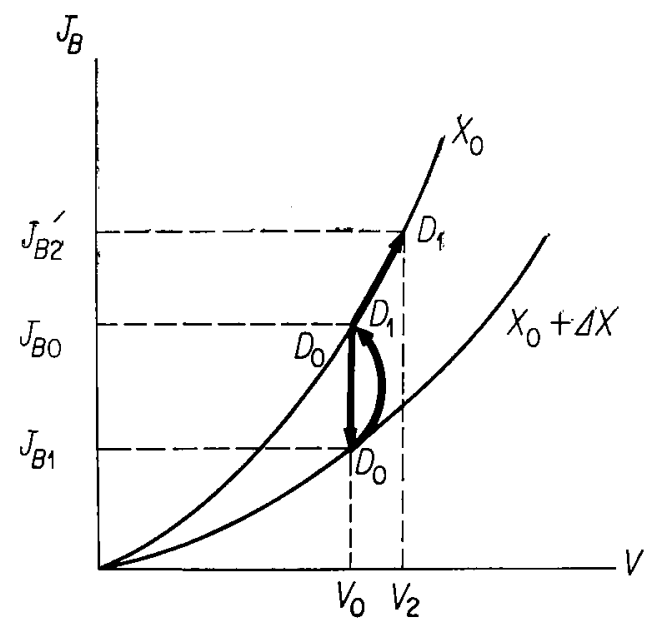

第 17 四最適通転位冝への遷移を含む制御 $J_{B}-V$ 面

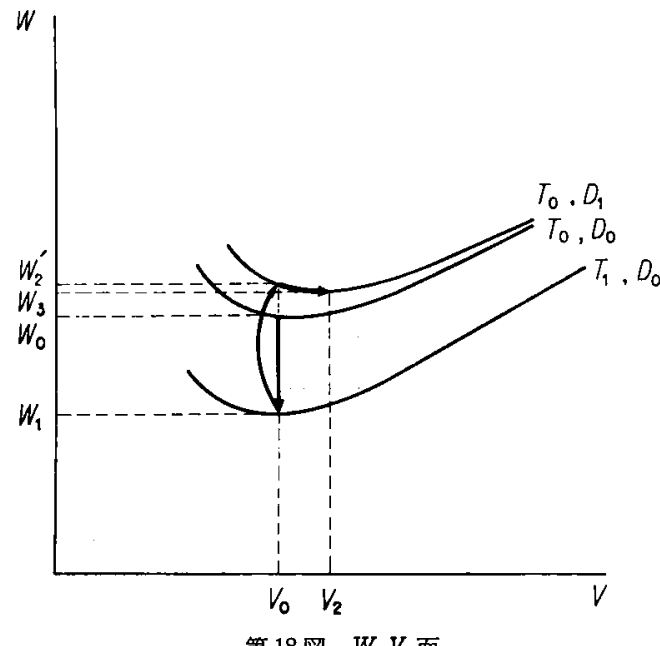

第18図 $W-V$ 面

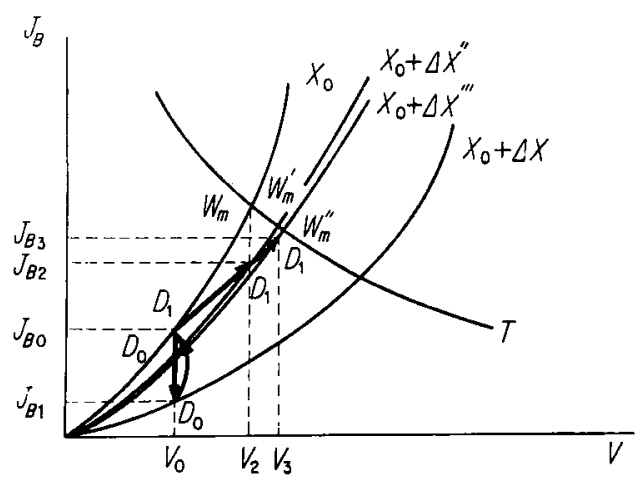

第19図第 17 四においてプラズマ境界位要の変化を 考慮した場合

より可能でこの電圧変化でプラズマ境界面が変化する ことも考慮した場合の制御過程は，第 19 図に示され る. このような最適運転位置への制御は，電圧電流の 変化のみならず，噴射時間も変化する. 


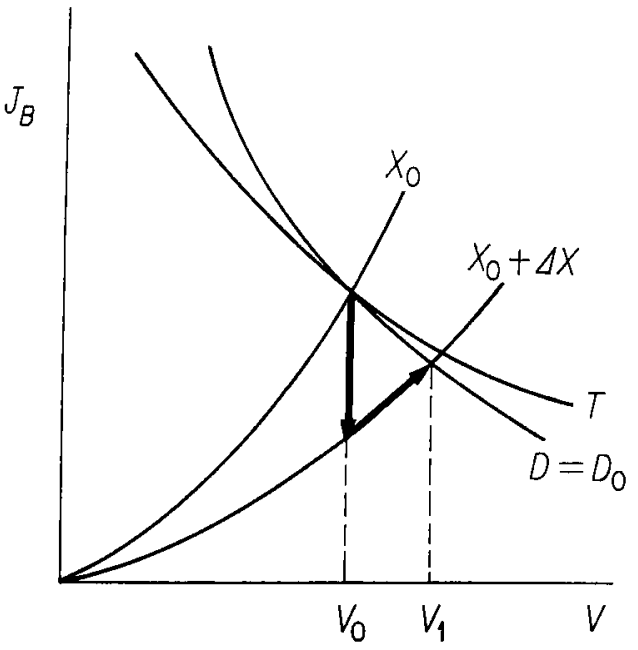

第20困 噴射時間の变化を含む加速電王変化による補償

第 1 表 各制御法の比較

\begin{tabular}{|c|c|c|c|c|}
\hline & $\Delta W_{V}$ & \multicolumn{2}{|c|}{$\Delta W_{\mathrm{d} \mid \mathrm{s}}$} & $\Delta W_{t}$ \\
\hline & & \multicolumn{2}{|c|}{ 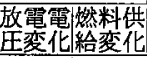 } & \\
\hline 燃 料 増 減 & 無 & 無 & 有 & 無 \\
\hline 燃料利用率変化 & 不変 & 不変 & 有 & 有 \\
\hline $\begin{array}{l}\text { アクセル・グリ } \\
\text { ッの損甥 }\end{array}$ & 不変 & 不変 & 変化有 & 変化有 \\
\hline 噴射時間変化 & 不変 & 不 & 変 & 有 \\
\hline $\begin{array}{l}\text { 最適運転位㯰へ } \\
\text { の逶移 }\end{array}$ & 可能 & & 能 & \\
\hline 備 & 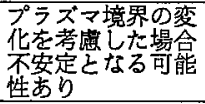 & & & 簡便 \\
\hline
\end{tabular}

第 20 図は，1）における制御が，加速電圧のみの 制御で噴射時間は変えなかったのに対し，制御に噴射 時間の変化をも許す場合のものである. すなわち， $x_{0}+\Delta x$ において，イオン生成コスト $D_{0}$ に対する最 適点を第 8 図加ら求め, その点へ加速電生を変化する あのである.

第 1 表は，上述の考慮を含めた制御法の比較であ る.

\section{5. 結 論}

ここでは，電子衝撃型イオン・エンジンを，与えら れたミッションに対し，最小の電力量ですむ最適運転 位置を明らかにし，制御法については，従来の流量制 御のみがいつも最適な制御法ではなく，種々の状況下 で，最適な方法が存在することを示した．とこでは， 電力量を中心に解析したが，プロペラントについて
あ，消費量を少なくすることはすちろん，てれが，エ ンジンの寿命に密接な関係を持つことから，以後の解 析には重要と思われる。

\section{参考文献}

1) Boucher, R. A. : Electrical propulsion for control of stationary satellites, J. Spacecraft and Rockets, vol. 1, (1964) pp 164-175.

2) MoLitor, T. H. : Application of ion thrust motors in attitude and position control of satellites, Physics and Technology of Ion Motors, Gordon and Breach Publ. (1966).

3) Anderson, J.R. and Cybulski, R. J. : Status and application of low thrust electric propulsion systems, AIAA paper 66-578.

4) BARRET, C.C.: On the application of electric propulsion to satellite orbit adjustment and station keeping, AIAA paper 67-719.

5) Duck, K. I., Bartlett, R. O. and Sulliban, R. J. : Evaluation of an ion propulsion systems for a synchronous spacecraft mission, AIAA paper $67-720$.

6) Shatтuck, R. and Sohr, G.: Electric propulsion for satellite position and attitude control, AIAA paper 67-722.

7) Davision, G. J. : Orbit expansion by microthrust part 1 description of results, RAE Tech. Rep. No. 67249 (1967).

8) Openshaw, P.R. : Electric propulsion systems for European use, AIAA paper 69-274.

9) Gunther, F.A.: Electrostatic propulsion and mission analysis in the Federal Republic of Germany, AIAA paper 69-288.

10) Childs, G. W. and Stotr, D. : The orbital transfer of TV satellites by ion propulsion, Aero. J. Royạl Aero. Soc., Vol. 74, (1970) pp 925-934.

11) Free, B. A. : Economic tradeoff stadies for electric propulsion missions on communication satellites, AIAA paper 71-683.

12）上杉邦密，長友信人：太陽熱口ヶットにおける低推力 飛しょう径路の最適化，太陽電池のふく射による少化 を考虑して，東大宇宙研報告，Vol 4，(1968) pp. 307324.

13）山中龍夫，吉村庄一：䉓気推進による静止衛星への遷 移任必要な智制御，昭和 46 年度宇宙航行の力学シ ンポジウム (1971) pp. 105-112.

14）中村嘉宏，長友信人，中村邦男，工蕂勲：電子衙型 イオン推進機と弾道飛行訊験について，経団連経済智 料 No. 274 (1972) pp. 101-113.

15）工藤勲，村上寛，後関璋一，中山勝矢：電子衝型1 オン・エンシンン関する研究 (1) 試作一号機に関す る実験, 日本航宇学誌, Vol. 19 (1971) pp. 43-52.

16) KING, H. J. : private communication.

17) Kudo, I., Murakami, H. and Nakayama, K. : Control of electron bombardment ion engine for stationary satellite, Proceedings of 9 th International Symposium on Space Technology and Science (1971) pp. 99-106. 